AGRITECH, Vol. 37, No. 1, Februari 2017, Hal. 48-58 DOI: http://dx.doi.org/10.22146/agritech.17009 ISSN 0216-0455 (Print), ISSN 2527-3825 (Online) Tersedia online di https://jurnal.ugm.ac.id/agritech/

\title{
Pengurangan Kadar Digliserida dan Asam Lemak Bebas dalam Minyak Sawit Kasar Menggunakan Adsorben
}

\author{
Reduction of Diacylglyceride and Free Fatty Acid in Crude Palm Oil Using Adsorbents \\ Khoerul Bariyah ${ }^{1}$, Nuri Andarwulan ${ }^{1,2}$, Purwiyatno Hariyadi ${ }^{1,2}$ \\ ${ }^{1}$ Departemen Ilmu dan Teknologi Pangan, Fakultas Teknologi Pertanian, Institut Pertanian Bogor, \\ Jl. Lingkar Akademik Kampus IPB Darmaga Bogor 16680, Indonesia \\ ${ }^{2}$ Southeast Asian Food and Agricultural Science and Technology (SEAFAST) Center, Institut Pertanian Bogor, \\ Jl. Puspa No.1 Kampus IPB Darmaga, Bogor 16680, Indonesia \\ Email: nuri@seafast.org
}

Submisi: 15 Oktober 2015; Penerimaan: 19 Februari 2016

\begin{abstract}
ABSTRAK
Indonesia merupakan negara produsen sekaligus konsumen minyak sawit kasar (Crude Palm Oil/CPO) terbesar di dunia pada tahun 2014. Salah satu komponen yang mempengaruhi kualitas CPO adalah digliserida (DAG) dan asam lemak bebas (ALB). DAG dalam minyak sawit adalah prekursor pembentuk senyawa karsinogen 3-MCPD ester, sedangkan ALB yang tinggi dapat mempengaruhi stabilitas minyak. Proses kontak adsorben ke dalam CPO akan mempengaruhi keberadaan kedua komponen tersebut. Tujuan penelitian ini adalah untuk menentukan jenis adsorben yang paling baik dalam mengadsorp digliserida dan asam lemak bebas dalam CPO dengan menitikberatkan pada karakteristik adsorben dan adsorbat. Penelitian dilakukan terhadap 3 jenis CPO (nilai ALB: 4, 6, dan 14) dan 6 jenis adsorben (arang aktif, $\mathrm{MgO}$, Magnesol R-60, dan 3 jenis bleaching earth). Proses kontak dilakukan pada suhu $50-60{ }^{\circ} \mathrm{C}$ (tanpa vakum) untuk seleksi adsorben dan $90^{\circ} \mathrm{C}$ (dengan vakum) selama 30 menit dengan dosis adsorben 1 dan $3 \%$. Proses kontak adsorben pada CPO dengan kondisi adsorpsi tanpa vakum belum dapat menurunkan DAG dan ALB secara signifikan terhadap ketiga jenis CPO. Kombinasi antara adsorben bleaching earth tipe 1 dan $\mathrm{MgO}$ dapat menurunkan ALB hingga $70 \%$ pada CPO dengan ALB $14 \%$ pada kondisi vakum, tetapi tidak dapat menurunkan DAG. Karakterisitik CPO dan adsorben mempengaruhi proses reduksi ALB dan DAG.
\end{abstract}

Kata kunci: Adsorben; CPO; digliserida; asam lemak bebas

\begin{abstract}
Indonesia is the world's largest crude palm oil (CPO) producer and consumer in 2014. Components that affect the quality of CPO are diglycerides (DAGs) and free fatty acids (FFA). DAGs in palm oil are known as the precursor of 3-MCPD esters, while higher content of FFA could influence the oil stability. The contact of CPO with adsorbent could affect the present of DAG and FFA in CPO. The purpose of this study was to determine the best type of adsorbent in reducing DAGs and FFA in CPO with emphasis on the characteristics of the adsorbent and adsorbate. This study was carried out by using three different types of CPO quality and six different types of adsorbent (carbon active, $\mathrm{MgO}$, Magnesol R-60, and 3 types of bleaching earth). The contact process of CPO with different adsorbents were carried out at a temperature of $50-60{ }^{\circ} \mathrm{C}$ (without vacuum) for adsorbents selection and $90{ }^{\circ} \mathrm{C}$ (under vacuum) for 30 minutes at a dose of adsorbent 1 and $3 \%$. The contact process of different adsorbents with CPO have not been able to reduce both DAGs and FFA significantly at the non vacuum condition in three differents $\mathrm{CPO}$ sample. The combination of $\mathrm{MgO}$ and bleaching earth type 1 could reduce FFA up to $70 \%$ reaching the content of $14 \%$ at vacuum conditions, but did not reduce DAGs of CPO. Different CPO quality and adsorbent characteristics will affect the reduction process of FFA and DAGs.
\end{abstract}

Keywords: Adsorbents; CPO; diacylglyceride; free fatty acid 


\section{PENDAHULUAN}

Konsumsi minyak nabati dunia didominasi oleh minyak sawit (sebesar $41 \%$ ) menurut data Oil World 2014 (GAPKI, 2014). Pada tahun 2014, sekitar 55,2 \% (32 juta ton) dari total produksi minyak sawit kasar (Crude Palm Oil/CPO) dunia dikuasai oleh Indonesia. Selain itu, data Oil World dalam GAPKI (2014) juga menunjukkan bahwa Indonesia merupakan negara konsumen minyak sawit terbesar di dunia dalam kurun waktu 2010 - 2014, yaitu sebesar 15,8 $\%$. Karena pentingnya CPO di Indonesia, maka kualitas CPO yang dihasilkan harus sangat dijaga dan diperhatikan sehingga dapat memenuhi kebutuhan domestik maupun internasional.

Kualitas CPO ditentukan oleh besarnya kandungan komponen tertentu, diantaranya kandungan digliserida (DAG) dan kadar asam lemak bebas (ALB). DAG merupakan prekursor pembentuk senyawa karsinogenik 3-MCPD ester. $\mathrm{CPO}$ dari Indonesia mengandung kadar 3-MCPD ester tertinggi dibandingkan negara lainnya setelah melalui proses pemanasan standar (Matthäus dkk., 2011). Penelitian Lanovia dkk. (2014) terhadap sebelas sampel minyak goreng sawit menunjukkan bahwa kandungan DAG dalam minyak goreng sawit berkorelasi positif dengan kandungan 3-MCPD ester. Greyt (2010) juga menyatakan jika kadar DAG lebih besar dari $4 \%$, maka kadar 3-MCPD ester umumnya lebih besar dari 5 ppm. Adapun ALB yang tinggi dalam minyak sawit tidak diinginkan karena dapat menurunkan stabilitas minyak selama penyimpanan karena proses oksidasi maupun reaksi enzimatis (Ketaren, 1986).

CPO mengandung DAG dan ALB dengan kadar yang tinggi. Proses kontak beberapa jenis adsorben (dengan pemisahan kembali adsorben pada akhir reaksi) ke dalam CPO dapat mereduksi kedua senyawa tersebut, diantaranya lempung teraktifasi seperti zeolit dan bleaching earth (Strijowski dkk., 2011) dan material sintetik berbahan dasar silika (Clowutimon dkk., 2011; Ermacora dan Hrncirik, 2014). Penelitian Clowutimon dkk. (2011) menunjukkan bahwa magnesium silikat sintetik dari abu sekam padi dapat mengadsorp ALB dalam CPO hingga $130-140 \mathrm{mg} / \mathrm{g}$ adsorben pada suhu $50{ }^{\circ} \mathrm{C}$ selama 2 jam. Strijowski dkk. (2011) menambahkan beberapa adsorben ke dalam minyak sawit hasil pemurnian dan menunjukkan bahwa magnesium silikat (kadar $70 \%$ ) dan zeolit terkalsinasi dapat menurunkan DAG hingga $25 \%$ pada suhu $80^{\circ} \mathrm{C}$, tetapi adsorben lain tidak bisa mereduksi secara signifikan. Sedangkan Ermacora dan Hrncirik (2014) dapat menurunkan kadar DAG pada CPO yang dilarutkan dalam pelarut organik hingga $99 \%$ dengan kolom silika gel. Data Global Specialty Ingredient (materi promosi komersial) juga menunjukkan magnesium silikat sintetik (Magnesol R60) dapat menurunkan asam lemak bebas hingga $80 \%$ (dari 0,09 menjadi $0,012 \%$ ) dan menurunkan
DAG $20 \%$ (dari 4 menjadi 2,8\%) pada fraksi olein minyak goreng sawit. Reduksi DAG hasil penelitian - penelitian tersebut umumnya dilakukan terhadap minyak sawit hasil pemurnian dengan kandungan ALB yang rendah, padahal umumnya $\mathrm{CPO}$ mengandung ALB yang tinggi $(>3 \%)$.

Hingga saat ini belum ada penelitian mengenai reduksi DAG dengan kadar ALB yang cukup tinggi dalam CPO. Proses kontak beberapa adsorben (terutama persenyawaan magnesium silikat) ke dalam CPO kemungkinan dapat menurunkan kadar DAG dan ALB sehingga meningkatkan kualitas CPO. Oleh karena itu, perlu dipelajari pengaruh proses kontak adsorben pada $\mathrm{CPO}$ sebelum pemurnian untuk menurunkan kadar DAG dan ALB. Menurut Strijowski dkk. (2011) tidak semua adsorben dapat menurunkan komponen polar (seperti DAG) dalam minyak sawit. Hal tersebut dikarenakan karakterisitik dari adsorben sangat menentukan proses adsorpsi yang terjadi. Adsorben yang memiliki keasaman tinggi akan memiliki kemampuan adsorpsi yang lebih besar (Ahmadi dan Mushollaeni, 2007; Silva dkk., 2014). Sehingga tujuan penelitian ini adalah untuk menentukan jenis adsorben (dengan sifat kepolaran yang berbeda-beda) yang paling baik dalam mengadsorp DAG dan ALB dengan menitikberatkan pada karakteristik adsorben dan adsorbat. Modifikasi proses kontak berbagai jenis adsorben sebelum pemurnian diharapkan dapat meningkatkan kualitas CPO.

\section{METODE PENELITIAN}

\section{Bahan}

Bahan baku utama yang digunakan dalam penelitian ini adalah minyak sawit kasar (CPO/Crude Palm Oil) dengan 3 tingkat mutu berdasarkan nilai ALB dari pabrik pengolahan kelapa sawit di Kalimantan Selatan. Beberapa adsorben yang digunakan adalah Magnesol R60, MgO p.a (Merck), tiga jenis bleaching earth (tipe 1, 2 dan 3) komersial (dengan karakteristik adsorben pada Tabel 1) dan arang aktif p.a (Merck).

\section{Alat}

Peralatan utama yang digunakan untuk analisis adalah sentrifuse (IKA ${ }^{\circledR} \mathrm{C}-\mathrm{MAG}$ HS7), pompa vakum (Precision), GC-FID (HP 6890 Version A.01.11), X-ray Diffractometer(XRD Emma GBC), spektrofotometer UVVis (SHIMADZU 2450), spektroskopi FTIR (SHIMADZU IRPrestige-21), dan spektroskopi serapan atom (HITACHI Z-2000). Instrumen penunjang yang digunakan antara lain penangas air, stirer, kertas saring, termometer, dan peralatan gelas. 


\section{Persiapan dan Karakterisasi Bahan Baku}

\section{Karakterisasi CPO}

Bahan baku CPO yang digunakan terdiri dari 3 tingkat mutu berdasarkan nilai ALB (4, 6 dan 14\%). Sampel diuji kualitasnya berdasarkan metode pengujian standar untuk mengetahui kondisi awal sampel meliputi kadar air, total karoten, kadar ALB dan gliserida.

Kadar karoten CPO diukur berdasarkan metode spektrofotometri (PORIM, 2005). Sebanyak 0,1 g sampel dilarutkan sampai homogen dengan pelarut heksana dalam labu ukur $25 \mathrm{~mL}$. Selanjutnya, absorbansi larutan diukur dengan spektrofotometer pada panjang gelombang $446 \mathrm{~nm}$.

Kadar karoten dihitung menggunakan rumus:

Kadar karoten $(\mathrm{mgkg})=\frac{25 \mathrm{x} \text { absorbansi } \mathrm{x} 383}{100 \mathrm{x} \text { berat sampel }(\mathrm{g})}$

Profil asam lemak bebas dan kandungan gliserida $\mathrm{CPO}$ diukur dengan kromatografi gas (GC-FID) (AOCS Official Method Cd 11b-91, 2003). Sampel CPO sebanyak $25 \mathrm{mg}$ dimasukkan dalam vial kemudian ditambahkan $10 \mu \mathrm{L}$ tetra hidroksifuran dan $50 \mu \mathrm{L} N$-Trimetilsilan, divorteks dengan kecepatan $2.400 \mathrm{rpm}$ selama 1,5 menit kemudian disimpan dalam ruang gelap selama 10 menit. Selanjutnya sampel ditambahkan $2 \mathrm{~mL}$ heptana melalui pinggir tabung dan divorteks kembali dengan kecepatan $2.000 \mathrm{rpm}$ selama 30 detik kemudian ditutup rapat dengan parafilm dan didiamkan selama minimum 30 menit. Setelah itu sampel siap diinjeksikan ke dalam GC-FID sebanyak $1 \mu \mathrm{L}$. Kromatografi gas yang digunakan dilengkapi dengan split injeksi dan FID dengan kondisi sebagai berikut, suhu kolom awal $50{ }^{\circ} \mathrm{C}$ dinaikkan menjadi $180{ }^{\circ} \mathrm{C}$ dengan kenaikan $15{ }^{\circ} \mathrm{C} /$ menit, kemudian dinaikkan lagi menjadi $230{ }^{\circ} \mathrm{C}$ dengan kenaikan $7{ }^{\circ} \mathrm{C} /$ menit dan dinaikkan lagi menjadi $380^{\circ} \mathrm{C}$, suhu detektor $390^{\circ} \mathrm{C}$, suhu injektor $390{ }^{\circ} \mathrm{C}$, kecepatan gas pembawa $0,7 \mathrm{~mL} \mathrm{~N} /$ menit, kecepatan aliran udara $450 \mathrm{~mL} /$ menit dan volume injeksi 1 $\mu L$. Perhitungan kadar gliserida dan ALB dilakukan dengan menjumlahkan persentase luas area pada puncak kromatogram dan selang waktu retensi ALB, MAG, DAG, dan TAG.

\section{Karakterisasi Adsorben}

Adsorben sintetik (Magnesol R60, MgO, dan arang aktif) dikarakterisasi berdasarkan spesifikasi bahan pada label (Table 1), sedangkan tiga jenis bleaching earth dilakukan karakterisasi sifat fisikokimianya meliputi $\mathrm{pH}$, kadar air, kandungan oksida logam, pola difraksi $X$-Ray, dan pola spektra infra merah.

Nilai $\mathrm{pH}$ bleaching earth diukur menggunakan $\mathrm{pH}$ meter (Usman dkk., 2012). Sebanyak 5 g sampel direndam dalam $100 \mathrm{~mL}$ akuades selama kurang lebih 12 jam kemudian
Tabel 1. Karakteristik kimia adsorben yang digunakan berdasarkan informasi label kemasan dan analisis spektroskopi serapan atom

\begin{tabular}{|c|c|c|c|}
\hline Lambang & Jenis adsorben & Karakteristik & $\begin{array}{r}\text { Rasio mol } \\
\mathrm{MgO}: \mathrm{SiO}_{2}\end{array}$ \\
\hline Arang aktif & Arang aktif p.a & $>99 \%$ karbon $^{\mathrm{a}}$ & $0: 0$ \\
\hline $\begin{array}{l}\text { Bleaching earth } \\
\text { tipe } 1\end{array}$ & Bleaching earthalami & $\begin{array}{l}86 \% \mathrm{SiO}_{2}{ }^{\mathrm{c}} \\
1,1 \% \mathrm{MgO}\end{array}$ & $1: 57$ \\
\hline $\begin{array}{l}\text { Bleaching earth } \\
\text { tipe } 2\end{array}$ & Bleaching earthalami & $\begin{array}{l}94 \% \mathrm{SiO}_{2}{ }^{\mathrm{c}} \\
0,2 \% \mathrm{MgO}\end{array}$ & $1: 223$ \\
\hline $\begin{array}{l}\text { Bleaching earth } \\
\text { tipe } 3\end{array}$ & Bleaching earthalami & $\begin{array}{l}89 \% \mathrm{SiO}_{2}{ }^{\mathrm{c}} \\
0,7 \% \mathrm{MgO}\end{array}$ & $1: 86$ \\
\hline Magnesol R-60 & $\begin{array}{l}\text { Magnesium silikat } \\
\text { sintetik }\end{array}$ & $\begin{array}{l}65 \% \mathrm{SiO}_{2}^{\mathrm{b}} \\
15 \% \mathrm{MgO}\end{array}$ & $1: 3$ \\
\hline $\mathrm{MgO}$ & Magnesium oksida p.a & $>99 \% \mathrm{MgO}^{\mathrm{a}}$ & - \\
\hline
\end{tabular}

disaring dan diambil $25 \mathrm{~mL}$ untuk diukur nilai derajat keasamannya menggunakan $\mathrm{pH}$ meter.

Kadar air bleaching earth diukur berdasarkan berat kering (Sulaeman dkk., 2005). Sebanyak 5,00 g sampel ditimbang dalam cawan porselen yang telah diketahui bobotnya, kemudian dikeringkan dalam oven pada suhu $105^{\circ} \mathbf{C}$ selama 3 jam. Cawan diangkat dengan penjepit dan dimasukkan ke dalam desikator hingga dingin kemudian ditimbang.

Kandungan oksida logam bleaching earth diukur menggunakan metode spektroskopi serapan atom (Sulaeman dkk., 2005) melalui pengabuan basah dan diubah konsentrasi logam yang terukur ke dalam bentuk oksidanya berdasarkan Hukum Dalton.

Pola spektra infra merah bleaching earth diukur menggunakan spektroskopi FTIR (Djomgoue dan Njopwouo, 2013) pada range panjang gelombang $400-4.000 / \mathrm{cm}$ dengan resolusi $4 / \mathrm{cm}$.

Pola difraksi bleaching earth diukur menggunakan $X$-ray Diffractometer (Moore dan Reynolds, 1997) dengan sumber radiasi monokromator $\mathrm{Cu}-\mathrm{K} \alpha 1,54056 \AA(35 \mathrm{kV}$ dan $28,4 \mathrm{~mA}$ ). Pola difraksi dicatat antara $10^{\circ}-80^{\circ} 2 \theta$ dengan kecepatan $3 \%$ menit.

\section{Proses Kontak CPO dengan Adsorben tanpa Kondisi Vakum}

Sebanyak $100 \mathrm{~mL}$ sampel CPO dipanaskan hingga mencapai suhu $50{ }^{\circ} \mathrm{C}$, kemudian ditambahkan $1 \%(\mathrm{~b} / \mathrm{v})$ adsorben, diaduk menggunakan stirer (selama 30 dan 60 menit) dan didiamkan selama 10 menit. Setelah itu dilakukan pemisahan adsorben menggunakan sentrifuse (2500 rpm selama 15 menit). Selanjutnya CPO dikemas dalam botol gelap dan disimpan dalam refrigerator hingga siap untuk 
Tabel 2. Formulasi adsorben pada kondisi tanpa vakum

\begin{tabular}{cccc}
\hline Kombinasi adsorben & $\begin{array}{c}\text { Konsentrasi } \\
(\% \text { dalam } \mathrm{b} / \mathrm{v})\end{array}$ & $\begin{array}{c}\text { Suhu proses } \\
\left({ }^{\circ} \mathrm{C}\right)\end{array}$ & $\begin{array}{c}\text { Waktu } \\
(\text { menit })\end{array}$ \\
\hline $\begin{array}{c}\text { Bleaching earth tipe } 1 \\
\text { Bleaching earth tipe } 2\end{array}$ & 1 dan 3 & 50 dan 60 & 30 dan 60 \\
Bleaching earth tipe 3 & 1 dan 3 & 60 & 30 \\
Arang aktif & 1 dan 3 & 60 & 30 \\
$\begin{array}{c}\text { MgO } \\
\text { BgO }+ \text { Bleaching earth }\end{array}$ & 1 & 60 & 30 \\
tipe 1 & 1 & 60 & 30 \\
\hline
\end{tabular}

dianalisis (Strijowski dkk., 2011). Kontak juga dilakukan pada suhu $60{ }^{\circ} \mathrm{C}$ selama 30 menit dan variasi konsentrasi adsorben ( 1 dan $3 \%$ b/v). Kombinasi suhu pada proses kontak dilakukan di atas suhu titik leleh CPO (Franke dkk., 2009; Zulkurnain dkk., 2013), sedangkan konsentrasi adsorben didasarkan pada aturan maksimum penggunaan adsorben untuk proses pemurnian CPO (sebesar $1 \%$ ) dengan sedikit modifikasi (Tabel 2). Dari setiap perlakuan kemudian dilakukan analisis kualitas minyak yang dihasilkan meliputi kadar total karoten, kadar asam lemak bebas, dan kadar digliserol. Hasil yang diperoleh dijadikan acuan untuk proses kontak dengan kondisi vakum.

\section{Proses Kontak CPO dengan Adsorben pada Kondisi Vakum}

Adsorben hasil kontak paling baik dengan kondisi tanpa vakum digunakan untuk proses ini dengan ditambahkan Magnesol R-60 sebagai pembanding. Proses kontak dilakukan sesuai dengan tahap bleaching pada proses pemurnian $\mathrm{CPO}$ secara umum, yaitu dilakukan pada suhu $90{ }^{\circ} \mathrm{C}$ selama 30 menit, diaduk menggunakan stirer dan didiamkan selama 10 menit (Zulkurnain dkk., 2013). Pemisahan sampel menggunakan sentrifuse (2.500 rpm, 15 menit) dan selanjutnya CPO dikemas dalam botol gelap dan disimpan dalam refrigerator hingga siap untuk dianalisis. Proses kontak dilakukan pada suhu yang lebih tinggi dari proses sebelumnya
Tabel 3. Formulasi adsorben pada kondisi vakum

\begin{tabular}{cccc}
\hline Kombinasi adsorben & $\begin{array}{c}\text { Konsentrasi } \\
(\% \text { dalam b/v) }\end{array}$ & $\begin{array}{c}\text { Suhu } \\
\text { proses }\left({ }^{\circ} \mathrm{C}\right)\end{array}$ & $\begin{array}{c}\text { Waktu } \\
(\text { menit })\end{array}$ \\
\hline Magnesol (R-60) & 1 dan 3 & 90 & 30 \\
MgO & 1 & 90 & 30 \\
Bleaching earth tipe 1 & 1 & 90 & 30 \\
$\mathrm{R}-60+$ Bleaching earth tipe $1 *$ & 1 & 90 & 30 \\
$\mathrm{MgO}+$ Bleaching earth tipe $1 *$ & 1 & 90 & 30 \\
\hline * menggunakan variasi perbandingan kombinasi adsorben $1: 1 ; 1: 2 ;$ dan $2: 1$ \\
$(\%$ dalam b/v)
\end{tabular}

(tanpa kondisi vakum) dengan beberapa kombinasi adsorben (Tabel 2).

\section{Analisis Data}

Data dianalisis menggunakan metode analisis stastistika korelasi Pearson untuk mengetahui pengaruh karakteristik adsorben terhadap reduksi DAG dan ALB.

\section{HASIL DAN PEMBAHASAN}

\section{Karakterisasi CPO}

Bahan baku utama yang digunakan adalah tiga jenis CPO dengan kualitas yang berbeda berdasarkan nilai ALB. Kadar air dan total karoten CPO yang digunakan dalam penelitian ini masih memenuhi standar kualitas CPO menurut Standar Nasional Indonesia (SNI), akan tetapi kadar asam lemak bebas dua CPO (dengan nilai ALB 6 dan 14) tidak memenuhi standar SNI maupun Malaysia Standar (MS). Perbedaan kadar awal dari setiap komponen akan mempengaruhi proses adsorpsi apabila dikontakkan dengan adsorben (MorenoCastilla 2004). Hasil karakterisasi ketiga jenis CPO disajikan pada Tabel 3.

\section{Karakterisasi Adsorben}

Adsorben merupakan bahan yang dapat mengadsorp bahan lain baik berupa padatan maupun cairan. Proses

Tabel 4. Karakteristik bahan baku minyak sawit kasar (CPO)

\begin{tabular}{|c|c|c|c|c|c|c|}
\hline \multirow{2}{*}{ Karakteristik kualitas } & \multirow{2}{*}{ CPO1 } & \multirow{2}{*}{$\mathrm{CPO} 2$} & \multirow{2}{*}{$\mathrm{CPO} 3$} & \multicolumn{3}{|c|}{ Standar mutu } \\
\hline & & & & $\mathrm{SNI}^{a}$ & Ordinary $^{b}$ & $\mathrm{MS}^{c}$ \\
\hline Kadar air (\%) & 0,084 & 0,135 & 0,731 & 2 & 0,1 & Maks.0,25 \\
\hline Total karoten $(\mathrm{mg} / \mathrm{kg})$ & 610,98 & 584,09 & 565,73 & 500 & $500-700$ & $474-689$ \\
\hline Asam lemak bebas (\%) & 4,03 & 6,19 & 14,00 & Maks.5 & $3-5$ & Maks. 5 \\
\hline Digliserida (\%) & 6,97 & 8,28 & 5,59 & - & - & - \\
\hline Trigliserida (\%) & 89,00 & 85,53 & 80,41 & - & - & - \\
\hline
\end{tabular}

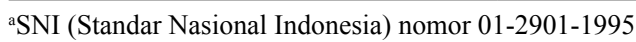

${ }^{b}$ Ketaren (1986)

${ }^{\mathrm{C}}$ MS (Malaysian Standard MS814:2007) 
adsorpsi dapat terjadi karena adanya interaksi atau gaya tarik menarik antara adsorbat dengan sisi-sisi aktif di permukaan adsorben baik secara fisika maupun kimia (Atkins, 1999). Pemilihan adsorben dilakukan berdasarkan polaritas adsorben dan ketersediaannya secara komersial untuk digunakan dalam proses pemurnian minyak sawit.

Rasio mol $\mathrm{MgO} / \mathrm{SiO}_{2}$ (Tabel 4) menunjukkan bahwa magnesol R-60 mempunyai rasio mol $\mathrm{MgO} / \mathrm{SiO}_{2}$ terkecil. Rasio perbandingan jumlah antar logam menentukan ukuran pori sebagai media interaksi dengan adsorbat. Penelitian Clowutimon dkk. (2011) menunjukkan bahwa semakin kecil rasio mol $\mathrm{MgO} / \mathrm{SiO}_{2}$ maka diameter pori adsorben akan semakin besar dan mempengaruhi kemampuan adsorpsi. Sehingga urutan kenaikan diameter pori berdasarkan rasio mol $\mathrm{MgO} / \mathrm{SiO}_{2}$ adalah bleaching earth tipe $2<$ bleaching earth tipe $3<$ bleaching earth tipe $1<$ Magnesol R-60. Karakteristik fisikokimia ketiga tipe bleaching earth disajikan pada Tabel 5 .

Tabel 5. Karakteristik fisik dan kimia bleaching earth komersial

\begin{tabular}{lccc}
\hline Karakteristik & $\begin{array}{c}\text { Bleaching } \\
\text { earth tipe 1 }\end{array}$ & $\begin{array}{c}\text { Bleaching } \\
\text { earth tipe 2 }\end{array}$ & $\begin{array}{c}\text { Bleaching earth } \\
\text { tipe 3 }\end{array}$ \\
\hline Warna & $\begin{array}{c}\text { Putih } \\
\text { kecoklatan }\end{array}$ & Coklat muda & $\begin{array}{c}\text { Coklat agak } \\
\text { gelap }\end{array}$ \\
Kadar air (\%) & 13,43 & 13,86 & 15,40 \\
$\mathrm{pH}$ & 3,10 & 3,50 & 5,00 \\
Kandungan oksida & & & \\
logam (\%): & & & \\
$\mathrm{SiO}_{2}$ & 85,67 & 94,35 & 88,69 \\
$\mathrm{MgO}_{2}$ & 1,11 & 0,28 & 0,69 \\
$\mathrm{Al}_{2} \mathrm{O}_{3}$ & 3,14 & 1,96 & 4,40 \\
$\mathrm{Fe}_{2} \mathrm{O}_{3}$ & 0,51 & 0,50 & 0,50 \\
$\mathrm{CaO}$ & 9,57 & 2,92 & 5,72 \\
\hline
\end{tabular}

Tabel 5 menunjukkan bahwa ketiga tipe bleaching earth memiliki karakteristik yang berbeda. Secara fisik, ketiga tipe bleaching earth memiliki kenampakan warna yang berbeda. Bleaching earth tipe 1 berwarna coklat paling muda, sedangkan bleaching earth tipe 3 berwarna coklat paling gelap. Perbedaan karakteristik akan mempengaruhi kemampuannya dalam mengadsorp adsorbat. Tingkat keasaman bleaching earth tipe 1 lebih tinggi dibandingkan yang lainnya. Secara umum semakin asam suatu adsorben, maka semakin tinggi tingkat adsorptivitas adsorben (Ahmadi dan Mushollaeni, 2007; Silva dkk., 2014). Adapun besarnya kandungan logam dalam bleaching earth akan mempengaruhi kristalinitasnya.

Analisis menggunakan spektroskopi FTIR terhadap ketiga tipe bleaching earth (Tabel 6) menunjukkan nilai bilangan gelombang puncak masing-masing gugus fungsi yang terdeteksi oleh alat FTIR. Spektrum tersebut menunjukkan gugus fungsi dari adsorben maupun pengotor yang ada dalam sampel. Puncak utama yang memberikan informasi adanya silika quartz $\left(\mathrm{SiO}_{2}\right)$ adalah munculnya spektra khusus yang menunjukkan vibrasi dari gugus siloksan ( $=\mathrm{Si}-\mathrm{O}-\mathrm{Si}=)$ dan silanol $(=\mathrm{Si}-\mathrm{OH})$. Deformasi unsur aluminium dan silikat pada spektrum tersebut menunjukkan adanya mineral monmorilonitte yang diperkuat dengan munculnya puncak spektra XRD pada $62^{\circ} 2 \theta$.

Analisis XRD terhadap ketiga tipe bleaching earth (Gambar 1) memperlihatkan pola difraksi yang hampir sama dengan intensitas puncak berbeda. Puncak utama terlihat pada $26^{\circ} 2 \theta$ adalah Quartz $\left(\mathrm{SiO}_{2}\right)$. Perbedaan intensitas puncak terlihat pada $26^{\circ} 2 \theta$ dengan intensitas puncak tertinggi pada bleaching earth tipe 1. Perbedaan intensitas puncak tersebut akan mempengaruhi kemampuan adsorpsi dari ketiganya. Adanya bukit agak lebar pada $15^{\circ} 2 \theta$ hingga $35^{\circ} 2 \theta$ menunjukkan karakteristik dari mineral yang amorf sehingga mineral ini memiliki kemampuan adsorbsi,

Tabel 6. Spektra FTIR ketiga tipe bleaching earth komersial

\begin{tabular}{|c|c|c|c|}
\hline \multirow{2}{*}{ Gugus fungsi } & \multicolumn{3}{|c|}{ Bilangan gelombang $\left(\mathrm{cm}^{-1}\right)$} \\
\hline & Bleaching earth tipe 1 & Bleaching earth tipe 2 & Bleaching earth tipe 3 \\
\hline Vibrasi ulur -OH terikat logam & $3.641,66$ & $3.616,53$ & $3.643,53$ \\
\hline Vibrasi ulur O-H dari (=Si-OH) & $3.440,94$ & $3.439,08$ & $3.441,01$ \\
\hline Vibrasi ulur $\mathrm{C}=\mathrm{O}$ & $1.634,46$ & $1.631,78$ & $1.614,42$ \\
\hline $\begin{array}{l}\text { Vibrasi ulur asimetris }=\mathrm{Si}-\mathrm{O} \text { dari }(=\mathrm{Si}- \\
\mathrm{O}-\mathrm{Si}=)\end{array}$ & $1.047,74$ & $1.055,91$ & $1.039,63$ \\
\hline $\begin{array}{l}\text { Vibrasi ulur simetris }=\text { Si-O dari }(=\mathrm{Si}-\mathrm{O}- \\
\mathrm{Si}=)\end{array}$ & 800,70 & 798,53 & 796,60 \\
\hline Deformasi $\mathrm{Al}-\mathrm{O}-\mathrm{Si}=$ & $522 ; 692$ & $522 ; 692$ & $514 ; 694$ \\
\hline $\begin{array}{l}\text { Vibrasi tekuk }=\text { Si-O dari } \\
(=\mathrm{Si}-\mathrm{O}-\mathrm{Si}=)\end{array}$ & 476,46 & 455,20 & 470,63 \\
\hline
\end{tabular}



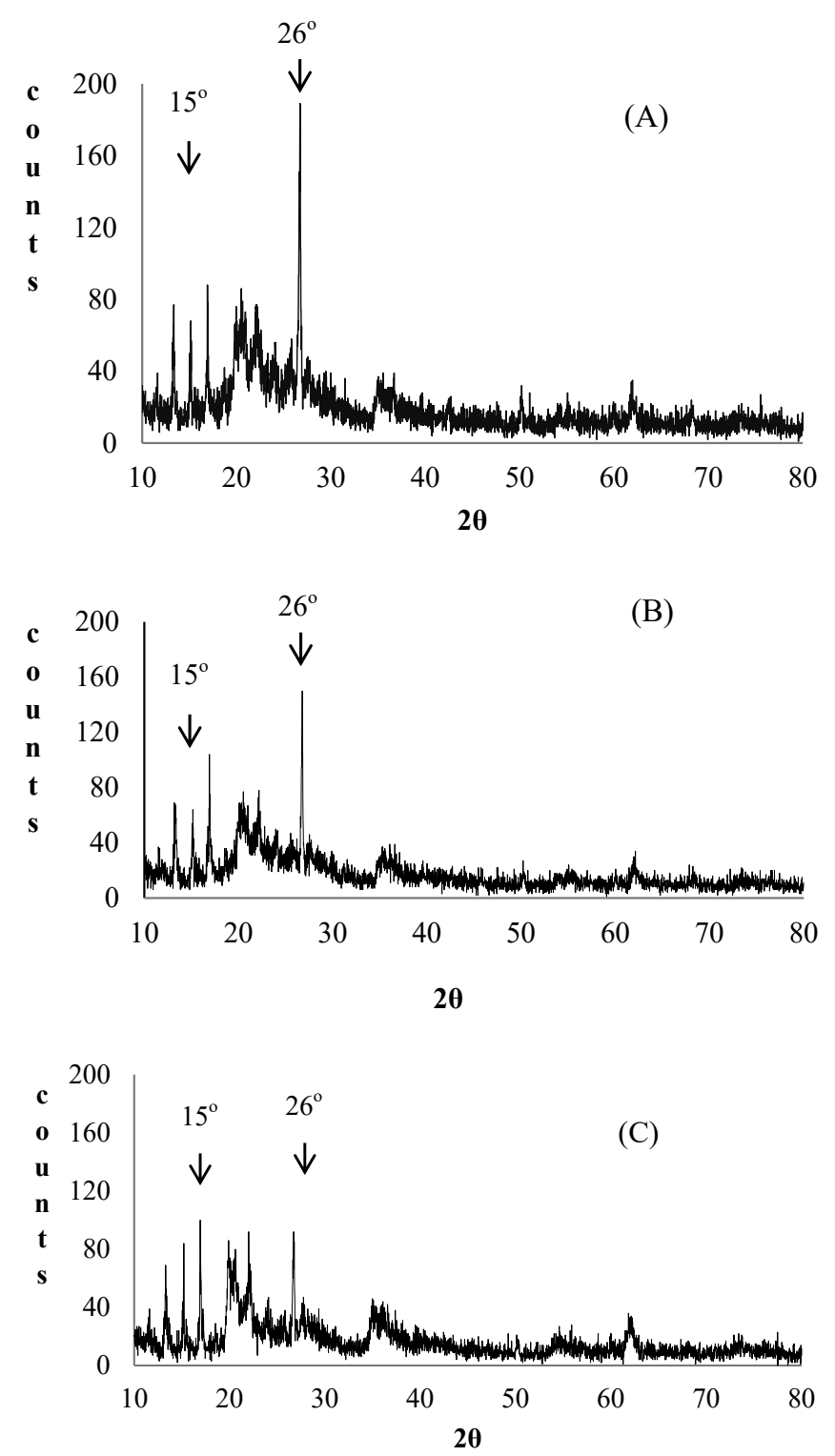

Gambar 1. Spektra XRD bleaching earth (A) tipe 1, (B) tipe 2, (C) tipe 3

sesuai dengan penelitian Kim dkk. (2008). Adapun derajat kristalinitas dari $\mathrm{SiO}_{2}$ dalam ketiga bleaching earth berturutturut 21,12\%, 10,73\% dan 10,65\%. Derajat kristalinitas tersebut menunjukkan banyaknya kandungan kristal $\mathrm{SiO}_{2}$ dalam bleaching earth.

\section{Proses Kontak CPO dengan Adsorben tanpa Kondisi Vakum}

Proses ini dilakukan dengan melakukan kontak ketiga jenis CPO tanpa kondisi vakum dengan beberapa adsorben (Tabel 1). Secara umum terjadi penurunan baik kadar DAG maupunALB (Gambar 2), tetapi penurunannya tidak signifikan sesuai dengan hasil penelitian Strijowski dkk. (2011).
Perlakuan waktu dan suhu kontak tetap tidak memberikan pengaruh yang signifikan. Rendahnya reduksi DAG dan ALB diduga karena masih banyaknya pengotor dalam CPO dan viskositas yang tinggi sehingga mempengaruhi proses adsorpsi (Huang dan Sathiviel, 2010).

Hasil reduksi DAG dan ALB pada kondisi tanpa vakum dibandingkan dengan beberapa penelitian lainnya (Tabel 7). Hasil kontak CPO (dengan nilai awal ALB 6,19 dan DAG 8,28) terlihat bahwa nilai ALB dan DAG mengalami perubahan, namun tidak signifikan. Beberapa data menunjukkan bahwa kadar DAG bahkan mengalami kenaikan. Hal tersebut dikarenakan ALB lebih mudah terjerap oleh adsorben karena ukuran molekulnya lebih kecil daripada DAG sehingga lebih mudah mengisi ruang kosong pori dalam adsorben dan jumlahnya menjadi berkurang. Sedangkan DAG susah terjerap oleh adsorben (jumlahnya tetap dalam larutan) sehingga persentasenya menjadi lebih besar.

Hasil penelitian ini didukung oleh beberapa data penelitian lain (Tabel 7) yang menunjukkan bahwa tidak semua adsorben dapat menurunkan kadar senyawa DAG dengan baik. Pada penelitian oleh Ermacora dan Hrncirik (2014) adsorben dapat menurunkan DAG hingga $99 \%$, akan tetapi dilakukan pelarutan CPO terlebih dahulu dan jumlah adsorben yang digunakan lebih banyak dari sampel. Pelarutan CPO akan menurunkan viskositas larutan sehingga mempermudah proses adsorpsi melalui interaksi kepolaran (Huang dan Sathiviel, 2010). Sedangkan Strijowski dkk. (2011) melaporkan bahwa adsorben dapat menurunkan DAG hingga $18 \%$, akan tetapi sampel yang digunakan adalah minyak goreng sawit dengan kadar ALB sangat rendah $(0,12$ $\%$ ) dibandingkan sampel CPO (>3\%). Selain itu, jumlah adsorben yang digunakan juga lebih besar dibandingkan dengan jumlah adsorben pada penelitian ini.

Hasil analisis korelasi Pearson terhadap ketiga sampel CPO pada kondisi tanpa vakum juga menunjukkan tidak ada pengaruh yang signifikan antara kandungan oksida adsorben

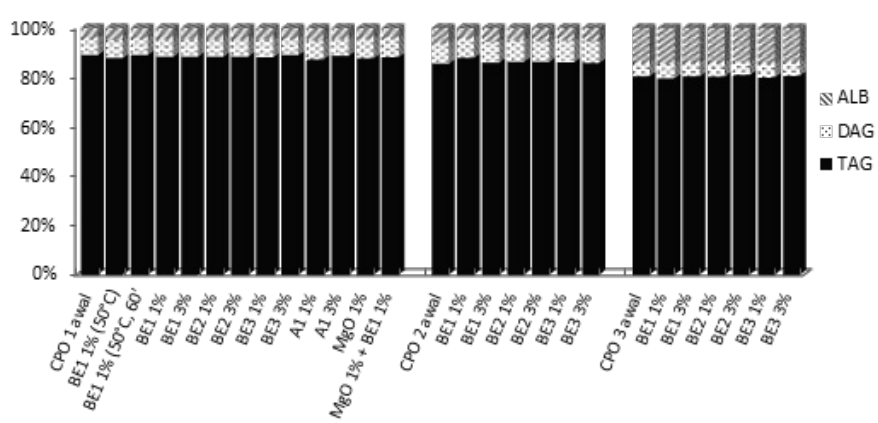

Gambar 2. Perubahan kadar DAG dan ALB proses kontak CPO dengan beberapa adsorben tanpa kondisi vakum 
Tabel 7. Perbandingan reduksi ALB dan DAG pada kondisi tanpa vakum

\begin{tabular}{|c|c|c|c|c|c|c|c|}
\hline \multirow{2}{*}{ Sampel } & \multicolumn{2}{|c|}{ Kondisi } & \multicolumn{4}{|c|}{ Hasil } & \multirow{2}{*}{ Referensi } \\
\hline & $\mathrm{T}\left({ }^{\circ} \mathrm{C}\right)$ & $\mathrm{T}(\mathrm{s})$ & ALB & $\%$ * & DAG & $\%{ }^{*}$ & \\
\hline $\begin{array}{l}500 \text { g CPO dalam } 400 \mathrm{~mL} \text { eter dilewatkan } \\
\text { dalam } 600 \mathrm{~g} \text { silika }\end{array}$ & - & - & - & - & & & $\begin{array}{l}\text { Ermacora dan Hrncirik } \\
\text { (2014) }\end{array}$ \\
\hline - Sebelum & & & & & 9,60 & - & \\
\hline - Setelah & & & & & $<0,1$ & 99 & \\
\hline $\mathrm{CPO}+$ adsorben & 60 & 30 & & & & & Hasil penelitian \\
\hline - Awal & & & 6,19 & - & 8,28 & - & \\
\hline - $\quad$ BE1 $1 \%$ & & & 4,22 & 31,8 & 8,03 & 3,02 & \\
\hline - $\quad$ BE1 $3 \%$ & & & 5,56 & 10,2 & 8,56 & $(+) 3,4$ & \\
\hline - $\quad$ BE2 $1 \%$ & & & 5,07 & 18,1 & 8,61 & $(+) 3,9$ & \\
\hline - $\quad$ BE2 3\% & & & 5,40 & 12,8 & 8,33 & $(+) 0,6$ & \\
\hline - $\quad$ BE3 $1 \%$ & & & 5,29 & 14,6 & 8,69 & $(+) 5,0$ & \\
\hline - $\quad$ BE3 $3 \%$ & & & 5,43 & 12,3 & 8,85 & $(+) 6,9$ & \\
\hline Fraksi olein CPO + adsorben $(3: 1)$ & 60 & 171 & & & - & - & Sirait (2007) \\
\hline - Awal & & & 5,06 & - & & & \\
\hline - atapulgit & & & 3,67 & 27,5 & & & \\
\hline - arang aktif & & & 2,97 & 41,3 & & & \\
\hline $\begin{array}{l}180 \mathrm{~g} \text { minyak goreng sawit }+20 \mathrm{~g} \text { adsorben } \\
\text { persenyawaan silikat }\end{array}$ & 80 & 30 & & & & & Strijowski dkk. (2011) \\
\hline Awal & & & 0,12 & - & 8,85 & - & \\
\hline - $\quad$ AMS $97 \%$ & & & & & 8,00 & 10 & \\
\hline - $\quad$ AMS $70 \%$ & & & & & 7,25 & 18 & \\
\hline - $\quad$ AMS $40 \%$ & & & & & 8,25 & 7 & \\
\hline - Zeolit (20\% air) & & & & & 8,50 & 4 & \\
\hline - Zeolit terkalsinasi & & & & & 7,25 & 18 & \\
\hline - Silikon oksida & & & & & 8,50 & 4 & \\
\hline - SAS (Al) & & & & & 8,65 & 3 & \\
\hline - $\operatorname{SCS}(\mathrm{Ca})$ & & & & & 8,25 & 7 & \\
\hline - $\quad$ SMS (Mg) & & & & & 8,75 & 2 & \\
\hline
\end{tabular}

$\mathrm{BE} 1, \mathrm{BE} 2$ dan BE3 = bleaching earth tipe 1, tipe 2 dan tipe 3

$\mathrm{AMS}=$ Amorphous magnesium silicate, $\mathrm{SAS}=$ Sodium aluminium silicate,

$\mathrm{SCS}=$ Synthetic calcium silcate, $\mathrm{SMS}=$ Synthetic magnesium ssilcate

* persentase penurunan, $(+)$ terjadi kenaikan, (- ) tidak dilakukan analisis

Tabel 8. Pengaruh jenis adsorben terhadap kadar karoten CPO dengan ALB $4 \%$ pada kondisi adsorpsi tanpa vakum dengan dosis adsorben $1 \%$ pada suhu $60{ }^{\circ} \mathrm{C}$ selama 30 menit

\begin{tabular}{lcc}
\hline Jenis adsorben & $\begin{array}{c}\text { Kadar karoten } \\
(\mathrm{mg} / \mathrm{kg})\end{array}$ & \% Penurunan \\
\hline Tanpa adsorben & 610,98 & - \\
Bleaching earthtipe 1 & 457,19 & 25,17 \\
Bleaching earthtipe 2 & 495,68 & 18,87 \\
Bleaching earthtipe 3 & 604,08 & 1,13 \\
Arang aktif p.a (Merck) & 594,31 & 2,73 \\
MgO p.a (Merck) & 606,24 & 0,78 \\
MgO+ bleaching & & \\
earthtipe 1 & 508,43 & 16,78 \\
\hline
\end{tabular}

terhadap reduksi DAG maupun ALB. Keenam adsorben yang digunakan pada kondisi tanpa vakum belum menurunkan kedua komponen secara signifikan, tetapi dapat menurunkan kadar total karoten (Tabel 8).

Secara umum semakin tinggi suhu dan lama waktu kontak, total karoten yang terjerap semakin besar ditunjukkan dengan nilai kadarnya yang makin menurun. Hal tersebut sesuai dengan penelitian Nwabanne dkk. (2007) yang menunjukkan bahwa peningkatan efisiensi bleaching sebanding dengan peningkatan ukuran partikel, suhu, waktu dan dosis yang digunakan. Interaksi yang terjadi antara karoten dengan adsorben tidak hanya adsorpsi fisik, tetapi merupakan interaksi adsorpsi kimia sehingga diperlukan kesamaan sifat kepolaran atau energi yang lebih besar untuk terjadinya reaksi (Silva dkk., 2013; Nwabanne dkk., 2013). Urutan daya serap terhadap karoten secara berturut-turut $\mathrm{MgO}<$ bleaching 
earth tipe $3<$ arang aktif $<(\mathrm{MgO}+$ bleaching earth tipe 1$)$ $<$ bleaching earth tipe $2<$ bleaching earth tipe 1 (Tabel 8).

Pada perlakuan menggunakan kombinasi $\mathrm{MgO}$ dan bleaching earth tipe 1 kemampuan adsorpsi karoten meningkat dibandingkan dengan $\mathrm{MgO}$ tunggal. Hal tersebut menunjukkan bahwa terjadi efek sinergis antara kedua adsorben tersebut sesuai dengan hasil penelitian Rossi dkk. (2003) yang telah mengkombinasikan silika sintetik dengan lempung pemucat yang juga berdampak sinergis. Akan tetapi efek sinergis yang terjadi pada penelitian ini masih perlu dipelajari lebih lanjut.

Hasil karakterisasi bleaching earth (keasaman, rasio mol MgO: $\mathrm{SiO}_{2}$, dan spektra XRD) juga menunjukkan bahwa bleaching earth tipe 1 lebih tinggi kemampuan adsorpsinya sebagai adsorben dalam mengadsorp suatu senyawa dibandingkan tipe lainnya. Kedua adsorben ini kemudian digunakan untuk melakukan kontak CPO pada kondisi vakum yang diharapkan dapat menurunkan ALB dan DAG secara signifikan.

\section{Proses Kontak CPO dengan Adsorben pada Kondisi Vakum}

Proses kontak beberapa adsorben pada kondisi tanpa vakum belum menunjukkan pengurangan kadar DAG dan ALB yang signifikan. Oleh karena itu, dilakukan perubahan proses dengan menggunakan kondisi vakum pada suhu yang lebih tinggi. Suhu dan tekanan yang tinggi akan meningkatkan proses adsorpsi (Atkins, 1999). Adsorben yang digunakan adalah adsorben yang memberikan pengaruh besar terhadap penurunan karoten pada kondisi tanpa vakum dan ditambahkan Magnesol R-60 sebagai pembanding. Walaupun menggunakan suhu proses yang lebih tinggi dibandingkan kondisi tanpa vakum, ternyata proses reduksi DAG dan ALB memiliki pola yang hampir sama dengan proses kontak tanpa vakum. Kadar DAG dan ALB ada yang mengalami kenaikan, tetapi juga ada yang mengalami penurunan. Kemungkinan yang terjadi seperti pada kondisi tanpa vakum, yaitu ukuran ALB yang lebih kecil dari DAG juga mempengaruhi proses adsorpsi. Selain itu, adanya hidrolisis triasilgliserol menjadi

Tabel 9. Perbandingan reduksi ALB dan DAG pada kondisi vakum

\begin{tabular}{|c|c|c|c|c|c|c|c|}
\hline \multirow{2}{*}{ Sampel } & \multicolumn{2}{|c|}{ Kondisi } & \multicolumn{4}{|c|}{ Hasil } & \multirow{2}{*}{ Referensi } \\
\hline & $\mathrm{T}\left({ }^{\circ} \mathrm{C}\right)$ & $\mathrm{t}(\mathrm{s})$ & ALB & $\%^{*}$ & DAG & $\%{ }^{*}$ & \\
\hline $\begin{array}{ll}\mathrm{CPO}+\text { asam sitrat }+2 \% \text { adsorben } \\
- & \text { Awal } \\
- & \mathrm{ABE}^{\mathrm{a}}+0,09 \% \text { sitrat } \\
- & \mathrm{ABE}^{\mathrm{a}}+0,27 \% \text { sitrat } \\
- & \mathrm{NBE}^{\mathrm{a}}+0,09 \% \text { sitrat } \\
- & \mathrm{NBE}^{\mathrm{a}}+0,27 \% \text { sitrat } \\
\end{array}$ & 105 & 30 & $\begin{array}{l}4,6 \\
5,0 \\
5,0 \\
4,7 \\
4,8\end{array}$ & $\begin{array}{l}- \\
(+) 9 \\
(+) 9 \\
(+) 2 \\
(+) 4\end{array}$ & - & - & Silva dkk. (2014) \\
\hline $\begin{array}{l}\text { Minyak sawit pre-refined dan RDPO + Tonsil 0,8\% } \\
-\quad \text { pre-refined Sebelum } \\
-\quad \\
\text { pre-refined Setelah } \\
\text { - }\end{array}$ & 90 & 20 & - & - & $\begin{array}{l}6,03 \\
5,98 \\
5,29 \\
5,23\end{array}$ & $\begin{array}{l}- \\
1 \\
- \\
1\end{array}$ & Franke dkk. (2009) \\
\hline $\begin{array}{ll}\mathrm{CPO}+\text { adsorben } \\
- & \text { Awal } \\
- & \mathrm{BE} 11 \% \\
- & \text { Magnesol (Mgs) } 1 \% \\
- & \text { (Mgs+BE1) } 1 \% \\
- & (\mathrm{MgO}+\mathrm{BE} 1) 1 \% \\
\mathrm{CPO}+\text { adsorben } \\
-\quad \\
- & \text { Awal } \\
- & \text { BE1 } 1 \% \\
- & \text { Magnesol(Mgs) } 1 \% \\
- & (\mathrm{Mgs}+\mathrm{BE} 1) 1 \% \\
\end{array}$ & 90 & 30 & $\begin{array}{l}6,19 \\
5,27 \\
5,81 \\
6,42 \\
4,79 \\
\\
14,0 \\
12,9 \\
12,8 \\
12,3 \\
4,15 \\
\end{array}$ & $\begin{array}{c}- \\
15 \\
6 \\
(+) 4 \\
22,4 \\
\\
- \\
7,5 \\
8,4 \\
11,6 \\
70,4\end{array}$ & $\begin{array}{l}8,28 \\
7,35 \\
7,59 \\
7,76 \\
7,90 \\
\\
5,59 \\
6,15 \\
5,79 \\
5,46 \\
6,62 \\
\end{array}$ & $\begin{array}{c}- \\
11 \\
8,3 \\
6,3 \\
4,6 \\
\\
- \\
(+) 10 \\
(+) 4 \\
2,3 \\
(+) 18\end{array}$ & Hasil penelitian \\
\hline $\begin{array}{l}\text { Minyak goreng sawit + Magnesol 1\% } \\
\text { Awal } \\
\text { Akhir }\end{array}$ & 90 & 20 & $\begin{array}{l}0,090 \\
0,012\end{array}$ & $\begin{array}{l}- \\
80\end{array}$ & $\begin{array}{l}4,00 \\
2,80\end{array}$ & - & $\begin{array}{l}\text { Global Speciality } \\
\text { Ingredient (2014) }\end{array}$ \\
\hline 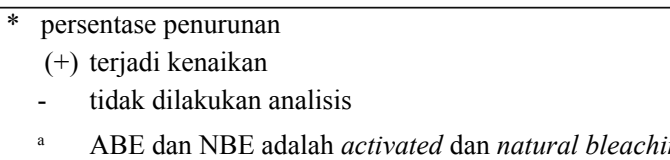 & earth & & & & & & \\
\hline
\end{tabular}


diasilgliserol dan asam lemak bebas yang justru dikatalisis oleh adsorben dapat menyebabkan kadar kedua senyawa naik. Hal tersebut karena sifat keasaman adsorben yang tinggi mempercepat proses hidrolisis. Hasil penelitian ini (Tabel 9) mendukung beberapa penelitian lain mengenai pengurangan kadar DAG dan ALB.

Hasil penelitian yang diperoleh sesuai dengan hasil penelitian Silva dkk. (2014) yang menambahkan bleaching earth teraktivasi asam maupun alami dan terjadi kenaikan ALB ( $\pm 9 \%$ ) dengan kadar awal 4,6 \%. Franke dkk. (2009) juga mengaplikasikan adsorben Tonsil OPT FF dalam CPO dan diperoleh penurunan diasilgliserol yang sangat kecil (tidak signifikan). Perbedaan terjadi dengan data Global Speciality Ingredient yang menunjukkan penurunan ALB hingga $80 \%$ (dari 0,09\% menjadi 0,012\%) dan DAG 30 $\%$ (dari $4 \%$ menjadi 2,8 \%) menggunakan Magnesol R-60. Pada hasil penelitian ini hanya menurunkan ALB sebesar $4 \%$ pada CPO (ALB 6) dan 8,4\% pada CPO (ALB 14), sedangkan DAG pada CPO (ALB 14) justru bertambah. Perbedaan tersebut kemungkinan terjadi karena jumlah kadar awal ALB dan DAG dari kedua jenis CPO berbeda sehingga mempengaruhi proses adsorpsi. Selain itu, viskositas kedua sampel juga berbeda karena jenis sampel yang digunakan berbeda. Global Speciality Ingredient menggunakan sampel minyak goreng sawit (ALB rendah), sedangkan penelitian ini menggunakan CPO (ALB tinggi).

Hasil kontak kombinasi bleaching earth tipe 1 dan $\mathrm{MgO}(1: 1)$ pada kedua CPO menunjukkan penurunan ALB yang lebih besar jika dibandingkan dengan hasil kontak kombinasi bleaching earth tipe 1 dan Magnesol R-60 (1:1). Kemungkinan yang terjadi adalah bahwa kombinasi bleaching earth tipe 1 dan $\mathrm{MgO}$ dapat meningkatkan kadar $\mathrm{MgO}$ dalam adsorben lebih tinggi dibandingkan dengan Magnesol R-60. Kenaikan kadar $\mathrm{MgO}$ dalam adsorben akan meningkatkan sifat kepolaran adsorben sehingga kemampuan adsorpsinya juga meningkat. Reduksi terbesar yang terjadi yaitu dengan adsorben kombinasi bleaching earth tipe 1 dan $\mathrm{MgO}(1: 1)$ sebesar $70 \%$ pada CPO dengan ALB 14. Kombinasi tersebut dapat menurunkan kadar ALB hingga menjadi 4,15\% yang memenuhi standar CPO, akan tetapi karoten juga berkurang (di bawah $500 \mathrm{mg} / \mathrm{kg}$ ) yang justru tidak memenuhi standar kualitas CPO.

Hasil analisis korelasi Pearson terhadap kedua jenis CPO (ALB 6 dan 14) menunjukkan bahwa tidak terjadi pengaruh signifikan antara kandungan adsorben terhadap reduksi DAG pada kedua jenis CPO, akan tetapi berpengaruh signifikan terhadap reduksi ALB pada CPO dengan ALB 14. Berdasarkan korelasi Pearson (Tabel 10), kadar $\mathrm{MgO}$ adsorben berkorelasi negatif dengan kadar ALB pada taraf nyata $5 \%$. Artinya bahwa semakin tinggi kadar $\mathrm{MgO}$, maka
Tabel 10. Korelasi matriks Pearson kandungan adsorben dan kadar ALB-DAG pada CPO dengan ALB 14

\begin{tabular}{lccc}
\hline Variabel & $\mathrm{SiO}_{2}$ & $\mathrm{MgO}$ & $\mathrm{DAG}$ \\
\hline $\mathrm{SiO}_{2}$ & $\mathbf{1}$ & & \\
$\mathrm{MgO}$ & $-0,107$ & $\mathbf{1}$ & \\
$\mathrm{DAG}$ & $-0,479$ & 0,372 & $\mathbf{1}$ \\
$\mathrm{ALB}$ & 0,049 & $\mathbf{- 0 , 6 1 7}$ & $\mathbf{- 0 , 6 8 5}^{\mathrm{a}}$ \\
\hline
\end{tabular}

${ }^{a}$ terdapat perbedaan yang signifikan pada taraf nyata $5 \%(\alpha=0,05)$

kadar ALB semakin kecil dan persentase penurunan ALB nya semakin besar.

Kenaikan kadar $\mathrm{MgO}$ tidak berpengaruh terhadap reduksi DAG dalam sampel CPO dengan ALB 14 karena kadar DAG awalnya rendah (sebesar 5,59), sedangkan kadar ALB awal tinggi (sebesar 14,00) sehingga kemungkinan ALB untuk terjerap lebih besar. Ukuran berat molekul ALB yang lebih kecil dibandingkan DAG juga menyebabkan ALB lebih mudah terjerap oleh adsorben. Hasil tersebut sesuai dengan data Global Speciality Ingredient(2014) yang menunjukkan penurunan DAG akan besar (hingga $30 \%$ ) apabila kadar ALB dalam sampel kecil (yaitu 0,012 \%). Persentase penurunan DAG juga lebih kecil dibandingkan persentase penurunan ALB sesuai dengan hasil penelitian. Oleh karena itu, karakteristik awal dari minyak sawit yang dikontakkan (adsorbat) kemungkinan mempengaruhi persentase penurunan DAG dan ALB pada CPO tersebut.

\section{KESIMPULAN DAN SARAN}

\section{Kesimpulan}

Keenam adsorben yang digunakan (dari non polar hingga polar) belum dapat mengurangi kadar DAG dan ALB secara signifikan pada ketiga jenis CPO, baik dengan kondisi vakum maupun tanpa vakum. Berdasarkan penelitian ini belum dapat diketahui karakteristik khusus adsorben yang dapat menurunkan DAG dan ALB. Pengurangan kadar terbesar, yaitu kombinasi antara adsorben bleaching earth tipe 1 dan $\mathrm{MgO}(1: 1)$ sebanyak $1 \%$, dapat menurunkan ALB hingga $70 \%$ pada CPO dengan ALB 14 pada kondisi vakum.

\section{Saran}

Untuk mendukung hasil penelitian ini, maka perlu dilakukan analisis rasio perbandingan DAG : ALB awal dalam berbagai CPO agar diketahui pola reduksi keduanya. Analisis pengaruh kandungan logam lainnya dalam adsorben (seperti Al dan $\mathrm{Ca}$ ) terhadap reduksi DAG dan ALB juga perlu diketahui untuk mengetahui karakteristik khusus adsorben yang dapat mereduksi kedua senyawa tersebut secara efektif. 


\section{UCAPAN TERIMA KASIH}

Penulis mengucapkan terima kasih kepada PT. Pola Kahuripan Inti Sawit Tanah Laut Kalimantan Selatan yang telah memberi dukungan dana untuk pelaksanaan penelitian ini.

\section{DAFTAR PUSTAKA}

AOCS (2003). American Oil Chemist's Society, Official Method. AOCS official method Cd 11b-91: Determination of mono-and diglycerides by capillary gas chromatofraphy. Sampling and analysis of commercial fats and oils. Hal. 1-5.

Ahmadi, Kgs. dan Mushollaeni, W. (2007). Aktivasi kimiawi zeolit alam untuk pemurnian minyak ikan dari hasil samping penepungan ikan lemuru (Sardinella longiceps). Jurnal Teknologi Pertanian 8: 71-79.

Atkins, P.W. (1999). Kimia fisika edisi kedua. Diterjemahkan oleh: Kartodadiprojo I, Erlangga. Jakarta.

Clowutimon, W., Kitchaiya, P. dan Assawasaengrat, P. (2011). Adsorption of free fatty acid from crude palm oil on magnesium silicate derived from rice husk. Engineering Journal 15: 15-26.

Djomgoue, P. dan Njopwouo, D. (2013). FT-IR spectroscopy applied for surface clays characterization. Journal of Surface Engineered Materials and Advanced Technology 3: 275-282.

Ermacora, A. dan Hrncirik, K. (2014). Study on the thermal degradation of 3-MCPD esters in model systems simulating deodorization of vegetable oils. Food Chemistry 150: 158-163.

Franke, K., Strijowski, U., Fleck, G., dan Pudel. F. (2009). Influence of chemical refining process and oil type on bound 3-chloro-1,2-propanediol contents in palm oil and rapeseed oil. LWT-Food Science Technology 42: 1751-1754.

GAPKI (2014). Industri minyak sawit Indonesia menuju 100 tahun NKRI. Edisipertama. Bogor, 2014. http://www. gapki.or.id/page/news/e-book. [26 Mei 2015].

Global Specialty Ingredient (2014). The power of Magnesol R60 in purification of vegetable oil, 2014. http://www. gsi-worldwide.com/downloads/product/fun_ing_pro_ aid_abs-082014.pdf. [28 Januari 2015].

Greyt (2010). Development in edible oil refining for the production of high quality food oils, 2010. http://
www.aocs.org/files/ResourcesPDF/refining_desmet ballestra.pdf. [15 September 2015].

Huang, J. dan Sathivel, S. (2010). Purifying salmon oil using adsorption, neutralization, and a combined neutralization and adsorption process. Journal of Food Engineering 96: 51-58.

Ketaren, S. (1986). Pengantar teknologi minyak dan lemak pangan. Universitas Indonesia. Jakarta.

Kim, M., Yoon, S.H., Choi, E. dan Gil, B. (2008). Comparison of the adsorbent performance between rice hull ash and rice hull silica gel according to their structural differences. LWT, Swiss Society of Food Science and Technology 41: 701-706.

Lanovia, T., Andarwulan, N. dan Hariyadi, P. (2014). Validasi metode weißhaar untuk analisis 3-MCPD ester dalam minyak goreng sawit. Jurnal Teknologi dan Industri Pangan 25: 200-208.

Matthäus, B., Pudel, F., Fehling, P., Vosmann, K. dan Freudenstein, A. (2011). Strategies for the reduction of 3-MCPD esters and related compounds in vegetable oils. Europe Journal Lipid Science and Technology 113 : 380-386.

Moore, D.M. dan Reynolds, R.C., Jr. (1997). X-ray diffraction and the identification and analysis of clay minerals, $2^{\text {nd }}$ ed. Oxford University Press. New York.

Moreno-Castilla, C. (2004). Adsorption of organic molecules from aqueous solutions on carbon materials. Carbon 42: 83-94.

Nwabanne, J.T. dan Ekwu, F.C. (2013). Decolourization of palm oil by Nigerian local clay: A study of adsorption isotherms and bleaching kinetics. International Journal Multidiscipline Science Engineering 4: 20-25.

PORIM. (2005). PORIM Test Methods Malaysia: Palm Oil Research Institute of Malaysia. Ministry of Primary Industries. Malaysia.

Rossi, M., Gianazza, M., Alamprese, C. dan Stanga, F. (2003). The role of bleaching clays and synthetic silica in palm oil physical refining. Food Chemistry 82: 291-296.

Silva, S., Sampaio, A.K., Ceriani, R., Verhé, R., Stevens, C., Greyt, W. dan Meirelles, A.J.. (2013). Adsorption of carotenes and phosphorus from palm oil onto acid. Journal of Food Engineering 118: 341-349.

Silva, S., Sampaio, A.K., Ceriani, R., Verhé, R., Stevens, C., Greyt, W. dan Meirelles, A.J. (2014). Effect of type of bleaching earth on the final color of refined palm oil. LWT-Food Science and Technology 59: 1-7. 
Sirait, K.E.E. (2007). Kinetika adsorpsi isotermal $\beta$-karoten olein sawit kasar dengan menggunakan atapulgit. Tesis. Institut Pertanian Bogor. Bogor.

Strijowski, U., Heinz, V. dan Franke, K. (2011). Removal of 3-MCPD esters and related substances after refining by adsorsbent material. Europe Journal Lipid Science and Technology 113: 387-390.

Sulaeman, Suparto dan Eviyati. (2005). Petunjuk teknis analisis kimia tanah, tanaman, air dan pupuk. Balai Penelitan Tanah Departemen Pertanian. Bogor.
Usman, M.A., Ekwueme, V.I., Alaje, T.O. dan Mohammed, A.O. (2012) Characterization, acid activation, and bleaching performance of ibeshe clay, Lagos, Nigeria, ISRN Ceramics, 2012. http://www.hindawi.com/ doi:10.5402/2012/658508. [30 April 2015].

Zulkurnain, M., Lai, O.M., Tan, S.C., Abdul, L.R., Tan, C.P. (2013). Optimization of palm oil physical refining process for reduction of 3-monochloropropane-1, 2-diol (3-MCPD) ester formation. Journal of Agricultural and Food Chemistry 61: 3341-3349. 